\title{
РЕАЛІЗАЦІЯ НАУКОВО-ПЕДАГОГІЧНОЇ ФУНКЦІї ВИКЛАДАЧА В КОНТЕКСТІ СТРАТЕГІЇ РОЗВИТКУ ВИЩОЇ ОСВІТИ В УКРАЇНI
}

Пропозичії підгрупі № 5 «Викладач майбутнього» робочої групи з розроблення проєкту Cmратегії розвитку вищої освіти в Україні на 2021-2031 роки https://doi.org/10.37472/2707-305X-2020-2-2-11-3

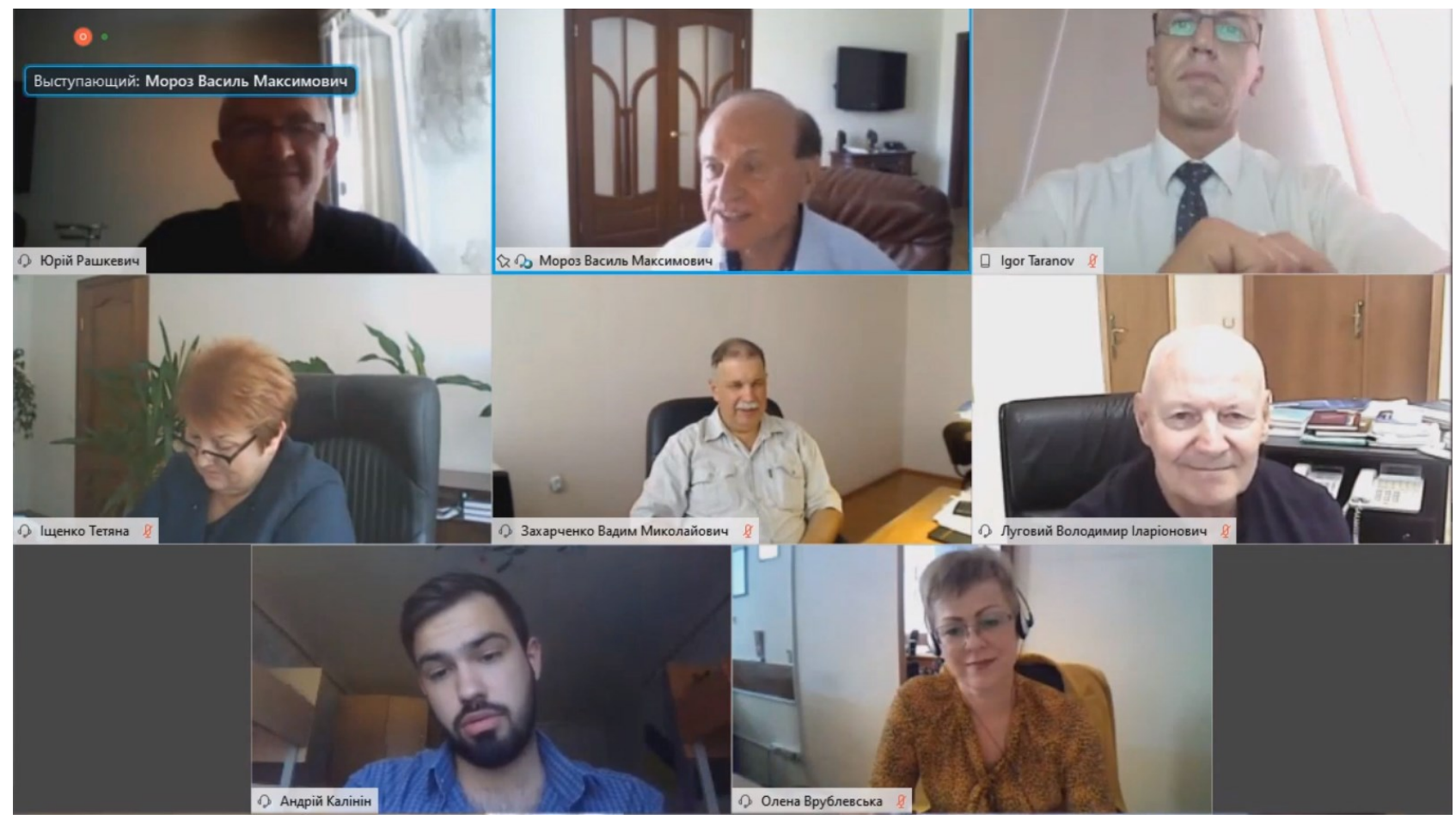

Фото: http://reform.org.ua/

\section{лУговИЙ}

\section{Володимир Іларіонович} доктор педагогічних наук, профресор, дійсний член (академік) НАПН України, перший віцепрезидент Начіональної академії педагогічних наук України, член робочої групи МОН України з розроблення проєкту Cтратегії розвитку вищої освіти в Україні на 2021-2031 роки, м. Київ, Україна

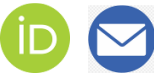

Анотація. 3 огляду на дуальну «науково-педагогічну» функцію університетського викладача обгрунтовано умови ії ефективної реалізації в конкурентоспроможному закладі вищої освіти. Серед цих умов - зниження навчального навантаження, підвищення конкурентоспроможності заробітної плати, необхідна i достатня навчальна, дослідницька, інформачійна інфраструктура закладу, посилення конкурсності відбору викладачів. У контексті стабілізації обсягів видатків на систему вищої освіти на рівні 1,2\% ВВП для створення зазначених умов насамперед потрібна оптимізація мережі закладів вищої освіти шляхом їх укрупнення, концентрації ресурсів, розвитку фінансової автономії для мотивації есрективної діяльності викладачів.

Ключові слова: науково-педагогічна функція викладача; навчальне навантаження; оплата праці; навчальна, дослідницька, інформачійна інфраструктура; конкурсний відбір; укрупнення закладів; концентрація ресурсів; фінансова автономія; мотивація.

За результатами участі 14 серпня 2020 р. у першому засіданні підгрупи № 5 «Викладач майбутнього» робочої групи 3 розроблення проєкту Стратегії розвитку вищої освіти в Україні 
на 2021-2031 роки (далі - Стратегія), утвореної наказом МОН України від 28 липня 2020 . № 974, запропоновано врахувати наступне.

1. У закладах вищої освіти (ЗВО) за основним місцем роботи зосереджено понад 70 \% наявних у національній економіці кандидатів і докторів наук. Їх двоаспектна «науково»-«педагогічна» функція як викладачів збережеться і в майбутньому. Однак нині вона реалізується незадовільно. Відтак, стратегічне завдання - упродовж 10 років створити умови для продуктивної та ефективної діяльності науково-педагогічних працівників.

2. 3-поміж причин недостатньої віддачі викладачів:

- велике за міжнародними мірками навчальне навантаження, що залишає обмаль часу на професійний («науковий» і «педагогічний») розвиток;

- мала, неконкурентоспроможна заробітна плата, що спонукає до підробітків, і ще більше мінімізує час на самовдосконалення;

- застарілість або відсутність необхідної і достатньої дослідницької, інформаційної й іншої інфраструктури для самопідготовки викладачів (для викладання - «із лабораторії в аудиторію») та для навчання здобувачів («із аудиторії в лабораторію»), реалізації так званого базованого на дослідженнях навчання;

- послаблення конкурсного відбору викладачів через роздутість мережі 281 ЗВО та великої кількості їх відокремлених структурних підрозділів (для порівняння, у Сполученому Королівстві з більшим у півтора рази населенням університетів 166, або в 1,7 рази менше, однак 65 з них, або 39 \%, увійшли в Шанхайський рейтинг 2020 р.).

3. Шляхи розв'язання проблеми:

- законодавче зниження та диференціація навчального навантаження викладачів залежно від складності програм (наприклад, у такий спосіб: загальне максимальне навантаження становить 500 год., при підготовці молодших бакалаврів так само 500 год., бакалаврів - 400, магістрів 300, аспірантів - 200, докторантів - 150 год.);

- підвищення заробітної плати науковопедагогічних працівників до подвійної від середньої в економіці України або: для асистента чотири, доцента - п'ять, професора - шість прожиткових мінімуми та надання права університетам у межах фінансової автономії встановлювати надбавки і доплати;

- урахування у вартості підготовки здобувачів витрат на створення необхідної дослідницької, інформаційної, матеріально-технічної інфраструктури;
- оптимізація університетської мережі до 140150 зВО шляхом їх укрупнення, консолідації та концентрації ресурсів у них без зменшення фінансування.

4. Ураховуючи, що в сферу вищої освіти України вже спрямовуються фінансові ресурси в обсязі 1,2 \% ВВП (2019р.), який відповідає аналогічним видаткам у середньому в 23 країнах $\in C-$ членах Організації економічного співробітництва та розвитку (також 1,2% ВВП у 2016 р.), основним резервом покращення фінансового становища закладів для зменшення навчального навантаження, підвищення заробітної плати, створення інфраструктури, залишається укрупнення подрібнених і розпорошених закладів та концентрація їх ресурсів шляхом об'єднання, зниження у такий спосіб питомих витрат. Цим шляхом ідуть університети Німеччини, Сполученого Королівства, Фінляндії, Франції, Китаю, Японії. Особливо вражаючими і повчальними є стратегічні заходи з об'єднання й укрупнення, підвищення конкурентоспроможності університетів, що здійснені в останні три роки у Франції. Як результат, у 2020 р. за конкурентоспроможністю закладів вищої освіти ця країна за Шанхайським рейтингом піднялася на третю позицію після США і Сполученого Королівства.

\section{СПИСОК ВИКОРИСТАНИХ ДЖЕРЕЛ}

Вища освіта в Україні у 2019 році : статистична інформація. (2020). Київ: Державна служба статистики України. http://www.ukrstat.gov.ua/

Воробйова, О., Дебич, М., Линьова, І., Луговий, В., Оржель, О., Слюсаренко, О., Таланова, Ж., \& Трима, К. (2018). Аналіз провідного вітчизняного та зарубіжного досвіду щодо оцінювання якості вимої освіти в умовах євроінтеграції (частина I) : аналітичні матеріали (В. Луговий, Ж. Таланова, ред.). Київ: ІВО НАПН України. https://bit.ly/2Ctk3Ei

Воробйова, О., Дебич, М., Луговий, В., Оржель, О., Слюсаренко, О., Таланова, Ж., \& Трима, К. (2019). Аналіз провідного вітчизняного та зарубіжного досвіду щодо оцінювання якості вищої освіти в умовах євроінтеграції (частина II) : аналітичні матеріали. (В. Луговий, Ж. Таланова, ред.). Київ: ІВО НАПН України. https://doi.org/10.31874/978-6177486-28-1-2019

Воробйова, О.П., Гриценко, М.В., Луговий, В.І., Оржель, О.Ю., Слюсаренко, О.М., Ставицький, А.В., Таланова, Ж.В., Ткаченко, В.П., \& Трима, К.А. (2017). Світоглядні пріоритети гуманізації вищої освіти : монографія (В.І. Луговий, Ж.В. Таланова, ред.). Київ: IBO НАПН України.https://bit.ly/2ZAPRPa Bcmyn.OCBITA.UA. (2020). https://vstup.osvita.ua/

Державна казначейська служба України. (2020). Річний звіт про виконання Державного бюджету України за 2019 рік. https://www.treasury.gov.ua/ua/filestorage/richnij-zvit-pro-vikonannya-derzhavnogobyudzhetu-ukrayini-za-2019-rik 
Закон України. (2014, 1 липня). Про вищу освіту (1556VII). http://zakon5.rada.gov.ua/laws/show/1556-18

Інформаційна система «Конкурс». (2020). Вступна кампанія 2019 року. http://vstup.info/\#2019

Луговий, В.І., Слюсаренко, О.М., \& Таланова, Ж.В. (2018а). Нові уроки лідерства для України від Шанхайського рейтингу 2018 року. Педагогіка і психологія. Вісник НАПН України, (3), 5-22.

Луговий, В.І., Слюсаренко, О.М., \& Таланова, Ж.В. (2018b). Організаційно-економічні засади реалізації дуальної «викладацько-дослідницької» функції науково-педагогічних працівників університетів. Вісник Київського національного університету технологій та дизайну, (Спецвипуск. VIII Міжнародна науково-практична конференція «Ефективність організаційно-економічного механізму інноваційного розвитку вищої освіти України»), 15-26. https://er.knutd.edu.ua/handle/123456789/10045

Луговий, В.І., Слюсаренко, О.М., \& Таланова, Ж.В. (2018c). Світовий досвід для створення національного рейтингу закладів вищої освіти. Педагогіка $i$ психологія. Вісник НАПН України, (2), 5-23.

Луговий, В.І., Слюсаренко, О.М., \& Таланова, Ж.В. (2019). Реалізація дослідницько-інноваційного потенціалу університетів як невід'ємного складника їх діяльності. Наука та наукознавство, (3), 26-45. https://doi.org/10.15407/sofs2019.03.026

Міністерство освіти і науки України. (2020, 28 липня). Про утворення робочої групи з розроблення проєкту Cтратегії розвитку вищої освіти України на 2021-2031 роки (974). http://reform.org.ua/

Президент України. (2020, 3 червня). Про вдосконалення вищої освіти в Україні (210). https:// www.president.gov.ua/documents/2102020-34045

Слюсаренко, О.М. (2015). Розвиток найвищого університетського потенціалу в умовах глобалізації : монографія. Київ: Пріоритети. https:// lib.iitta.gov.ua/10225/

Таланова, Ж.В. (2010). Докторська підготовка у світі mа Україні : монографія. Київ: Міленіум. https:// bit.ly/30Yv75J

Lugovyi, V., Orzhel, O., Slyusarenko, O., \& Talanova, Zh. (2018). Education and research duality - the determining characteristic of higher education. Education: Modern Discourses, (1), 71-88. https:// doi.org/10.32405/2617-3107-2018-1-8

Lugovyi, V., Slyusarenko, O. \& Talanova, Zh. (2019). University rating \& development: challenges and opportunities for Ukraine. Education: Modern Discourses, (2), 60-77. https://doi.org/10.32405/2617-3107-2019$1-8$

ShanghaiRanking Consultancy. (2020). Academic Ranking of World Universities 2020. http:// www.shanghairanking.com/ARWU2020.html

ShanghaiRanking Consultancy. (2020, June 29). ShanghaiRanking's Global Ranking of Academic Subjects 2020 Press Release. http://www.shanghairanking.com/ ShanghaiRankings-Global-Ranking-of-AcademicSubjects-2020-Press-Release.html

\section{REALISING THE ACADEMIC STAFF'S RESEARCH AND EDUCATIONAL FUNCTION IN THE CONTEXT OF THE STRATEGY FOR THE DEVELOPMENT OF HIGHER EDUCATION IN UKRAINE \\ Proposals for the Subgroup No 5 "Academic Staff of the Future" of the Working Group on Designing the Draft Strategy for the Development of Higher Education in Ukraine for 2021-2023}

\section{Volodymyr Lugovyi}

DSc in Education, Professor, Full Member (Academician) of NAES of Ukraine, First Vice-President, National Academy of Educational Sciences of Ukraine, Member of the Ministry of Education and Science of Ukraine Working Group on Designing the Draft Strategy for the Development of Higher Education in Ukraine for 2021-2023, Kyiv, Ukraine

Abstract. Due to the dual "research and educational" function of the academic staff, the conditions for its effective realisation in a competitive higher education institution are grounded. Among these conditions are: reducing the study load, increasing the competitiveness of salary; necessary and sufficient training, research and informational infrastructure of an institution; strengthening the competitiveness of the academic staff selection. In the context of stabilizing the expenditures on higher education system at 1.2 percent of GDP to assure the mentioned conditions, first of all, the higher education institutions network optimisation is needed by their consolidation, resource concentration and financial autonomy development to motivate the efficient activity of the academic staff.

Keywords: research and educational function of the academic staff; study load; remuneration; training, research and informational infrastructure; competitive selection; institutions' consolidation; resource concentration; financial autonomy; motivation.

Дата публікації: 18 серпня 2020 р 